\title{
Effects of Different Biogas Manures and Their Extracts on Dry Matter Yield and Nutrients Uptake by Faba Bean (vicia faba l.) Grown on Sandy Soil Conditions.
}

\author{
Amira M. Sabry ${ }^{1}$, Mohamed A. El-Ghozoli ${ }^{1}$ Ibrahim M. E. Ali ${ }^{2}$ and Heba S. A. Rashed ${ }^{2}$ \\ ${ }^{1}$ Agricultural Microbiology Department, Soil, Water and Environ. Research Inst. Agric. Research center, Giza, Egypt. \\ ${ }^{2}$ Soil and Water Department, Faculty of Agriculture, Moshtohor, Benha University, Egypt. \\ Corresponding Author: Heba S. A. Rashed \\ E-mail: heba.abdelmaabood@fagr.bu.edu.eg
}

\begin{abstract}
The current study evaluates the feasibility of amending a sandy soil with three different types of biogas manure (cattle dung alone BMC, cattle dung + jaw's mallow wastes BMJ and cattle dung + mango wastes $\mathrm{BMM}$ ) and their extractions (potassium humate HK, humic acid HA and fulvic acid FA) at two different rates (2 and 4\%) to increase NPK uptake by faba bean plants and enhance their growth. To attain this aim, a pot experiment was conducted for 60 days during the winter season of 2019 following a randomized complete block design (RCBD). A control treatment, that received the recommended dose of NPK mineral fertilizers, was also considered for data comparison. Results reveal that the BMC biogas manure recorded the highest increases in faba bean dry weights (6.40g/pot) comparing with the results of other biogas manures. Generally, biogas manures seemed to be more efficient than their extracts on improving NPK uptake by plants and hence increase plant dry weights. Moreover, increasing the rate of application from 2 to $4 \%$ recorded further significant increases in this concern. On the contrary, BMM biogas manure was the least efficient organic treatment that increased faba bean growth when applied at a rate of $2 \%(4.72 \mathrm{~g} / \mathrm{pot})$. Thus, it can be deduced that different biogas manures enhanced the uptake of N P K by plants and increased their growth vs the control, especially when applied at a rate of $4 \%$; yet the behavior of the organic amendments in soil varied considerably among the source of the organic amendment.
\end{abstract}

Keywords: Biogas manures, nutrients uptake, faba bean, sandy soil.

Introduction

Legume plants play key roles in sustainable agriculture (Jia and Gray, 2008). Faba bean (Vicia faba L.), in particular, is one of the most important legumes in Egypt (Cazzato et al., 2012) and probably in many areas around the world (Crepon et al., 2010 and Boghdady etal., 2017). Its symbiotic relation with $\mathrm{N}$-fixers can raise nitrogen content within different plant parts (Franche et al., 2009), especially protein in grains (Denton et al., 2013). These grains are consumed by both human and animals (Altuntaş and Yıldız, 2007) while crop residues can be used for fodder, silage purposes and to produce green manure (Sharaan et al., 2004; McVicar et al., 2013; and Nasser et al., 2016).

Organic matter (OM) is the life of soil (Reddy and Reddi, 1992) because it acts as a reservoir for macro- (N, P, K) and micro-nutrients (Farid et al., 2014 and 2018; Elshony et al., 2019). Also, organic amendments lessen nutrients losses by leaching from the top soil (Buckman and Brady, 1980; Pardo et al., 2014). Accordingly, it is recommended to amend soils with organic amendments to increase their fertility and supply plants with nutrient needed for their growth (Gomaa. and Attia, 1998 and Rizk and Shafeek, 2000) e.g. faba beans (Mohamed, 2001) and wheat (Farid et al., 2014). Moreover, organic amendments may effectively control soilborne diseases and pests (Lazarovits et al., 2001; McSorley, 2011), stimulate the activities of beneficial microbes (Liu et al., 2009) and increase plant tolerance to water stress (Quilty and Cattle, 2011). Generally, organic amendments (OA) can be categorized into two main groups: (1) compost-based amendments that include composts, vermicomposts, and their teas and (2) non-compost-based ones include biostimulants such as humic extracts and seaweed extracts (Du Jardin, 2015 and Macdonald et al., 2018). These amendments are used commercially in plant production worldwide (Ameri and Tehranifar, 2012) . Biogas is one of the most economically viable and environmentally friendly renewable energy resources (Deublein and Steinhauser, 2011). It is produced during anaerobic digestion (AD) of organic materials through multiple complicated biochemical reactions (Rajaeifar et al., 2017). The current study considers the production biogas from different sources i.e. cattle dung alone and/or food preserving industry wastes to study their impacts on plant growth. We assume that the outcomes of the investigated organic amendments vary considerably according to the sources of these amendments. In case of cattle dung, it compost can positively improve growth parameters of different plants (Boghdady et al., 2017), The ability of humic substances to improve plant growth and development is widely investigated by many researchers (Olaetxea et al., 2019) and humic acid, in particular, can induce plant resistance against soil borne pathogens (Eid et al., 2019). 
Large volumes of solid wastes are generated annually during food processing industry and these wastes present one of the serious problems in developing countries (Ozmen and Aslanzadeh, 2009). According to the FAO (2019), about $33 \%$ of the human food, $(\approx 1.3$ billion tons $)$, is wasted annually worldwide. Production of food wastes occurs during all stages of food supply, including agricultural processing, sorting, storing, transporting, distributing, selling, preparing, cooking, and serving (Xu et al., 2018). These wastes are thought to have direct economic consequences of about US\$ 750 billion annually (Peixoto and Pinto, 2016). Finally, future challenges and prospects of biogas production from food wastes are promising (Mirmohamadsadeghi et al., 2019).

The aim of the current work is to study the effects of three types of biogas manures (cattle dung alone $\mathrm{BMC}$, cattle dung + jaw's mallow processing wastes BMJ and cattle dung + mango processing wastes BMM) as well as their extracts (potassium humate- humic acid - fulvic acid) amended at 2 different rates (2 and 4\%) on faba bean yield and NPK uptake by plants grown on a low fertile sandy soil.

\section{1- Materials and Methods:}

\subsection{1-Soil of study: -}

Surface soil samples $(0-30 \mathrm{~cm}$ depth) were collected from El-Dair, Qalubia Governorate, Egypt. These samples were air dried, finely grounded to pass through a $2 \mathrm{~mm}$ sieve then thoroughly mixed to be homogenous and stored in plastic bags for experimental work., Chemical and physical properties of soil were investigated aa outline by Page et al. (1982) and Klute (1986) and the results are presented in Table 1.

Table 1. Chemical and physical properties of the investigated soil.

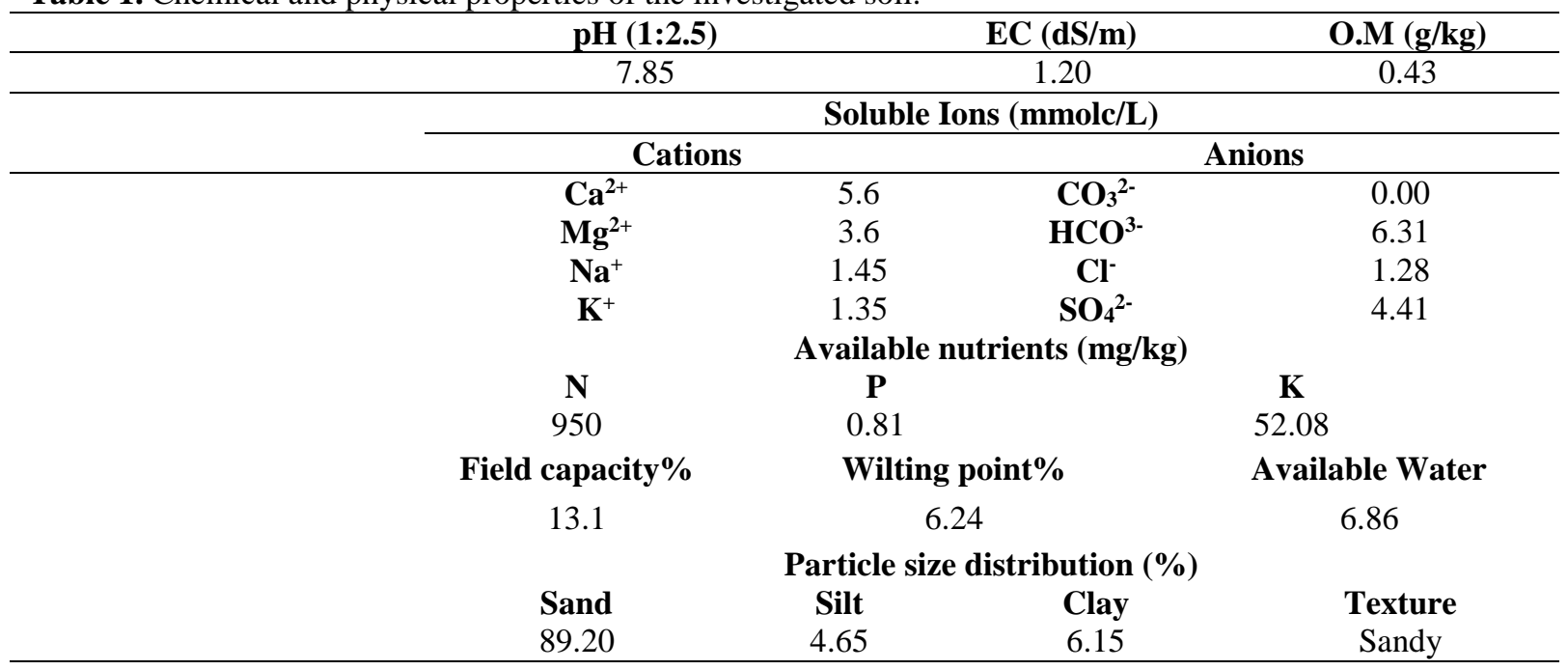

\section{Preparation of the different types of biogas manures.}

Food industries wastes.

Food industry wastes (Jew's mallow and mango wastes) were collected from The United Company for Food Industry, Montana and Qaha food industries, Qalubia Governorate, Egypt. These wastes were air dried, chopped into small pieces (1-2 $\mathrm{cm}$ ) before being used. Characteristics of the used organic residues are shows in Table 2.

\section{Animal wastes.}

Cattle dung was collected from the experimental station of faculty of agriculture at Moshtohor, Benha University. The animal wastes were air dried, shredded and prepared for an anaerobic fermentation experiment. Its characteristics are shown in Table 2.

Cuttle dung was then fermented for 60 days under anaerobic conditions either solely or in combination with food wastes mixed at a rate of 1:1) to attain the following (each treatment replicated twice):

1- Biogas manure produced from cattle dung alone (BMC).

2- Biogas manure produced from cattle dung alone + Jew's mallow (BMJ).

3- Biogas manure produced from cattle dung + mango processing wastes (BMM).

Analysis ofthree biogas manures produced from different raw materials as shown in Table 3. 
Table 2. Chemical and physical analysis of raw materials in the study.

\begin{tabular}{|c|c|c|c|}
\hline \multirow[t]{2}{*}{ Type of analysis } & \multicolumn{3}{|c|}{ Raw material } \\
\hline & Cattle dung & Jew's mallow wastes & Mango wastes \\
\hline PH (1:10) & 7.30 & 6.5 & 6.18 \\
\hline EC dSm-1 (1:10) & 4.15 & 2.51 & 3.85 \\
\hline $\mathrm{NH}_{4}-\mathrm{N}$ mg kg${ }^{-1}$ & 444.46 & 184 & 116 \\
\hline $\mathrm{NO}_{3}-\mathrm{N} \mathrm{mg} \mathrm{kg}{ }^{-1}$ & 24.70 & 78 & 32 \\
\hline Total-N \% & 1.61 & 1.13 & 1.05 \\
\hline Total-P \% & 0.75 & 0.60 & 0.47 \\
\hline Total-K\% & 1.70 & 0.46 & 0.26 \\
\hline Organic matter \% & 58.41 & 73.50 & 95.0 \\
\hline Organic carbon $\%$ & 33.88 & 42.6 & 55.1 \\
\hline $\mathrm{C} / \mathrm{N}$ ratio & 21.04:1 & $37.70: 1$ & $52.5: 1$ \\
\hline Total coliform $\mathrm{cfu} / \mathrm{g}$ & $35 \times 10^{3}$ & $31 \times 10^{3}$ & $29 \times 10^{3}$ \\
\hline Fecal coliform cfu/g & $24 \times 10^{2}$ & $17 \times 10^{2}$ & $15 \times 10^{2}$ \\
\hline $\begin{array}{l}\text { Salmonella and } \\
\text { shigella } \mathrm{cfu} / \mathrm{g}\end{array}$ & $12 \times 10^{2}$ & $11 \times 10^{2}$ & $7 \times 10^{2}$ \\
\hline
\end{tabular}

Table 3. Physical, chemical and biological analyses for three different biogas manures after fermentation of the raw materials.

\begin{tabular}{|c|c|c|c|}
\hline \multirow[t]{2}{*}{ Type of analysis } & \multicolumn{3}{|c|}{ Type of biogas manures } \\
\hline & BMC & BMJ & $\overline{\mathbf{B M M}}$ \\
\hline PH (1:10) & 7.51 & 8.27 & 7.39 \\
\hline EC dSm-1 (1:10) & 3.75 & 2.72 & 2.25 \\
\hline NH4-N mg kg-1 & 250 & 336 & 403 \\
\hline NO3-N mg kg-1 & 521 & 580 & 648 \\
\hline Total-N \% & 1.64 & 1.79 & 2.11 \\
\hline Total-P \% & 0.52 & 0.98 & 0.91 \\
\hline Total- K \% & 0.73 & 0.32 & 0.33 \\
\hline Organic matter\% & 50.9 & 57.8 & 64 \\
\hline Organic carbon\% & 29.5 & 37.1 & 45.8 \\
\hline CIN ratio & $18: 1$ & $20.7: 1$ & $21.7: 1$ \\
\hline Ash gkg-1 & 49.1 & 21.2 & 54.0 \\
\hline Total coliform cfu/g & nd* & nd* & nd* \\
\hline Fecal coliform cfu/g & $\mathrm{nd}^{*}$ & nd* & $\mathrm{nd}^{*}$ \\
\hline $\begin{array}{l}\text { Salmonella and shigella } \\
\mathrm{cfu} / \mathrm{g}\end{array}$ & $\mathrm{nd}^{*}$ & nd* & $\mathrm{nd}^{*}$ \\
\hline Nematode larva & nd* & nd* & nd* \\
\hline Parasitic & $\mathrm{nd}^{*}$ & nd* & nd* \\
\hline Weed seed & nd* & nd* & $\mathrm{nd}^{*}$ \\
\hline
\end{tabular}

Note: nd: not detected, BMC: Cattel dung, BMJ: "Cattel dung + Jews mallow wastes" and BMM: "Cattel dung + Mango processing wastes".

Extraction and purification of humic and fulvic acids.

Extraction of humic and fulvic acids.

Extraction of humic substances was carried out according to the method described by Sanchez Monedero etal. (2002), as follow: humic substances were extracted from biogas manures by treating them with $0.5 \mathrm{~N} \mathrm{KOH}$ solution. Precipitates were known as potassium humate while the supernatents were then acidified with $\mathrm{HCl}$ to reach $\mathrm{pH} 2.0$, then left overnight. Humic acid precipitates were then separated from soluble fulvic acids by centrifuging at $6000 \mathrm{rpm}$ for 15 minutes.

\section{Humic acid purification.}

Humic acid precipitates were washed several times with cold $0.05 \mathrm{~N} \mathrm{H}_{2} \mathrm{SO}_{4}$ until the filtrate became colorless. Humic acid was then transferred to cellophane bags and dialyses against distilled water until the leachate became free of $\mathrm{Cl}^{-}$ions, then humic acid was left to dry in air (Chen et al., 1978).

\section{Fulvic acid purification}

Purification of fulvic acid was carried out as described by Kononova (1966) and Susilawti et al. (2007) as follows: the supernatant containing fulvic acid was passed through activated charcoal followed by elution of charcoal. The solution was concentrated and then transferred to the membrane filter and electrodialysis to set the dialysate free from chloride. Elementary analysis of humic and fulvic acids extracted from different biogas manures are shown in Table 4. 
Table 4. Elementary analysis of K-humate, humic acid (HA) and fulvic acid (FA) extracted from different samples.

\begin{tabular}{|c|c|c|c|c|c|c|c|c|c|c|}
\hline & $\mathrm{C} \%$ & $\mathbf{N \%}$ & H\% & O\% & $\mathrm{S} \%$ & $\begin{array}{c}\mathrm{C} / \mathrm{N} \\
\text { ratio }\end{array}$ & $\underset{\text { Ratio }}{\mathrm{C} / \mathrm{H}}$ & $\begin{array}{c}\text { C/O } \\
\text { Ratio }\end{array}$ & $\underset{\text { Ratio }}{\text { O/H }}$ & $\begin{array}{c}\text { N/H } \\
\text { Ratio }\end{array}$ \\
\hline & \multicolumn{10}{|c|}{ K-humate } \\
\hline BMC & 48.4 & 2.86 & 3.35 & 4.79 & 40.6 & 16.9 & 14.4 & 10.1 & 1.42 & 0.85 \\
\hline BMJ & 51.04 & 2.37 & 2.24 & 4.85 & 39.5 & 21.5 & 22.7 & 10.5 & 2.16 & 1.05 \\
\hline \multirow[t]{2}{*}{ BMM } & 50.5 & 3.27 & 1.96 & 3.71 & 40.5 & 15.4 & 25.7 & 13.6 & 1.89 & 1.6 \\
\hline & \multicolumn{10}{|c|}{ Humic acid (HA) } \\
\hline BMC & 57.1 & 5.6 & 5.1 & 30.1 & 2.1 & 10.2 & 11.2 & 2.0 & 5.9 & 1.1 \\
\hline BMJ & 53 & 4 & 7 & 34 & 2 & 13.2 & 7.5 & 0.13 & 4.8 & 0.57 \\
\hline \multirow[t]{2}{*}{ BMM } & 63 & 3 & 8 & 24 & 3 & 15.7 & 7.8 & 2.7 & 2.8 & 0.5 \\
\hline & \multicolumn{10}{|c|}{ Fulvic acid (FA) } \\
\hline BMC & 48.6 & 2.8 & 4.3 & 42 & 2.3 & 17.3 & 11.3 & 1.15 & 9.7 & 0.65 \\
\hline BMJ & 39 & 3 & 5 & 52 & 1 & 13 & 7.8 & 0.75 & 10.4 & 0.6 \\
\hline BMM & 45 & 2 & 5 & 46 & 2 & 22.5 & 9 & 0.97 & 9.2 & 0.4 \\
\hline
\end{tabular}

See footnote in Table 3.

The green house experiments.

A pot experiment was conducted at the Training Center for Recycling of Agriculture Residues (TCRAR) at Moshtohor, Qalubia Governorate (Soils, Water and Environment Research Institute (SWERI), Agricultural Research Center (ARC)) to investigate the impacts of amending a light textured soil with the three different biogas manures and their extracts (potassium humate- humic acid - fulvic acid) on faba bean dry weights and NPK uptake by plants. To attain this aim, two kilograms of air dried soil were packed in plastic pots $(16 \mathrm{~cm}$ height and $21 \mathrm{~cm}$ diameter) while considering the following treatments: Factor A: source of the organic amendment. Each pot received one of the following amendments: cattle dung (BMC), "cattle dung + Jews mallow wastes (BMJ)" and "cattle dung + Jews mallow wastes (BMM) or their extracts (HA, FH and HK) at two different rates (2 and 4\%). Four seeds of fabe been (Vicia faba,c.v Giza-2) were planted in each pot and the factorial experimental (3 factors) was arranged in a randomized complete block design with three replicates .All treatments received urea $(46 \% \mathrm{~N})$ at a rate of $30 \mathrm{~kg} \mathrm{Nha}^{-1}$ as a starter dose for microbial activation. Calcium calcium superphosphate $(8.5 \% \mathrm{P})$ and potassium sulphate $(48 \% \mathrm{~K})$ were also incorporate into soil before planting at rates of $75 \mathrm{kgP} \mathrm{ha}^{-1}$ and $48 \mathrm{~kg} \mathrm{~K} \mathrm{ha}^{-1}$, respectively.

After 10 days from cultivation, seedlings of faba beans were thinned to 3 plants per pot and the moisture content was kept at the field capacity during the experimental study by daily compensation of water loss with distilled water. After 60 days from germination, plants were harvested, oven dried at $70 \mathrm{C}$ for $48 \mathrm{~h}$ and the dry matter yield was recorded.

\section{Methods of analyses}

\section{Soil analyses}

Particle size distribution was determined by pipette method as described by Piper (1950). Organic matter content was estimated according to the method of Walkely and Black,outlined by
Jackson (1973), soil pH was measured in 1:2:5 soil water suspension using pH meter (EA920)electrical conductivity (EC) was measured in soil paste extract. Soluble cations and anions were determined in the soil paste extract according to the procedures followed by Page et al. (1982) as follows: calcium and magnesium by versenate method, sodium and potassium by flame photometer Model (ILAE201), carbonate and bicarbonate by titration against $\mathrm{HCl}$ and chloride was determined volumetrically using silver nitrate method. Sulphate was calculated as the differences between cations and anions. Soil moisture contents were determined according to Klute (1986).

\section{Plant analyses.}

Dried plant samples were finely ground in a porcelain mortar and subsamples of $0.5 \mathrm{~g}$ were acid digested using a mixture of sulphoric and perchloric acids (1:1) according to Page et al. (1982). Nitrogen was measured in plant extract by micro kjeldahl method, phosphorus was determined colormetrically by spectrophotometer (model6705 UV/Vis JENWAY) and potassium estimated by flame photometrically (model ILAE201) (Chapman and Pratt,1961).

Biogas manures analyses.

Electrical conductivity (EC) measurements were carried out in 1:10 biogas: water extract suspension (Richards, 1954) using EC meter (ICM Model 71150). Organic matter content of biogas manure was determined by glowing the biogas dried at $550 \mathrm{C}$ to a constant weight as recommended by Page etal. (1982). $\mathrm{pH}$ values of biogas manures were determined in 1:10 (manure: water) suspension using a glass electrode of Orion expandable ion analyzer EA920 according to Jodice et al. (1982). Total nitrogen was determined in the biogas manure using micro Kjeldahl method as described by Jackson (1973). Total phosphorus was determined using ascorbic acid method as outlined by Page et al. (1982). Total potassium of biogas manure digested was measured by flame photometer according to Chapman and pratt (1962). The number of total 
viable bacteria and fungi was determined by Reinhold et al. (1985). Ammonia and nitrate contents were determined according to Page et al. (1982).

\section{Statistical analysis}

The obtained results were subjected to analysis of variance according to Ryan and Joiner (1994) and the treatments were compared by using L.S.D at 0.05 level of probability.

\section{Results and Discussion.}

Dry matter yield of faba been plants grown on sandy soil as affected by different types of biogas manures and their extracts.

Three biogas manures (BMC, BMJ and BMM) and their extracts (HA, FA and HK) were tested for their effectiveness to increase the growth of faba bean plants (Vicia faba L.) grown on a sandy soil during winter season 2019 vs the non-amended control that received the recommended NPK doses as mineral fertilizers.

Data presented in Table 5 and illustrated in Fig 1 revealed that application of the three biogas manures and their extractives significantly increased the bean dry weight as compared with the control treatment. Where the values of this yield increased from $3.51 \mathrm{gpot}^{-1}$ up to $8.23,8.86$ and 5.18 gpot $^{-1}$ upon application of the BMC, BMJ and BMM, respectively. It could be concluded that the use of organic manures significantly increased the dry matter of faba bean plants grown on the tested sandy soil when compared the control treatment. These results stand in well agreement with those obtained by (Afifi,2010 and Lamhy,2004)

It is important to point out that the inducing effect of organic manuring on the productivity of light textured soils is due to the hums formed in the soil, which improved the physical and chemical properties of soil and supplies with some nutrient. These nutrients are like to be released from the organic matter after the decomposition by the microorganisms and then become available to plants. Theses organics increase soil fertility in light textured soils (EI-Ghozoli, 2018). Generally, as the rate of different types of biogas manures and their extracts applied increased from $2 \%$ to $4 \%$, the dry weight of bean plants also increased. Regarding the effect of types of humic substances applied which derived from different biogas manures, data indicated also that significant increases occurred due to manuring by humic substance, with no significant variation among between HA and FA treatments. In brief, the investigated treatments can be arranged according to their effect on dry matter yield of faba bean plants grown on the tested sandy soil in the following descending order: $\mathrm{OM}>\mathrm{HK}>\mathrm{FA}>\mathrm{HA}$. The positive effect of humic substances applied on dry matter yield productivity (Turan et al., 2011, Sani, 2014 and EL-Ghozoli, 2018)

Table 5. Dry mater yield $\left(\right.$ gpot $^{-1}$ ) of faba been plants grown on sandy soil as affected by different biogas manures and their extracts.

\begin{tabular}{|c|c|c|c|c|c|c|c|c|c|c|c|c|}
\hline Source (S) & & BMC & & & BMJ & & & BMM & & & and $n$ & an \\
\hline $\begin{array}{c}\text { Rate }(\mathbf{R}) \\
\text { Treatment (T) }\end{array}$ & $2 \%$ & $4 \%$ & Mean & $2 \%$ & $4 \%$ & Mean & $2 \%$ & $4 \%$ & Mean & $2 \%$ & $4 \%$ & Mean \\
\hline O.M & 3.80 & 6.56 & 5.18 & 8.46 & 9.26 & 8.86 & 6.43 & 10.03 & 8.23 & 6.23 & 8.57 & 7.40 \\
\hline HA & 4.96 & 5.40 & 5.18 & 4.66 & 5.53 & 5.09 & 4.83 & 5.93 & 5.38 & 4.81 & 5.62 & 5.21 \\
\hline FA & 5.03 & 6.30 & 5.67 & 4.93 & 4.73 & 4.83 & 5.90 & 5.60 & 5.75 & 5.28 & 5.54 & 5.41 \\
\hline HK & 5.10 & 5.86 & 5.48 & 5.86 & 5.76 & 5.81 & 5.00 & 7.44 & 6.23 & 5.32 & 6.36 & 5.84 \\
\hline Mean & 4.72 & 6.03 & 5.38 & 5.97 & 6.32 & 6.15 & 5.54 & 7.25 & 6.40 & 5.41 & 6.52 & 5.96 \\
\hline Control & \multicolumn{12}{|c|}{3.51} \\
\hline LSD at 0.05 & $\mathbf{S}=0$. & $1=$ & & 0.26 & $\mathbf{R} \times \mathbf{S}$ & & $\Gamma=0.5$ & $\mathbf{R} \mathbf{x}^{\prime}$ & 0.72 & $5 \times T \times R$ & $=1.02$ & \\
\hline
\end{tabular}

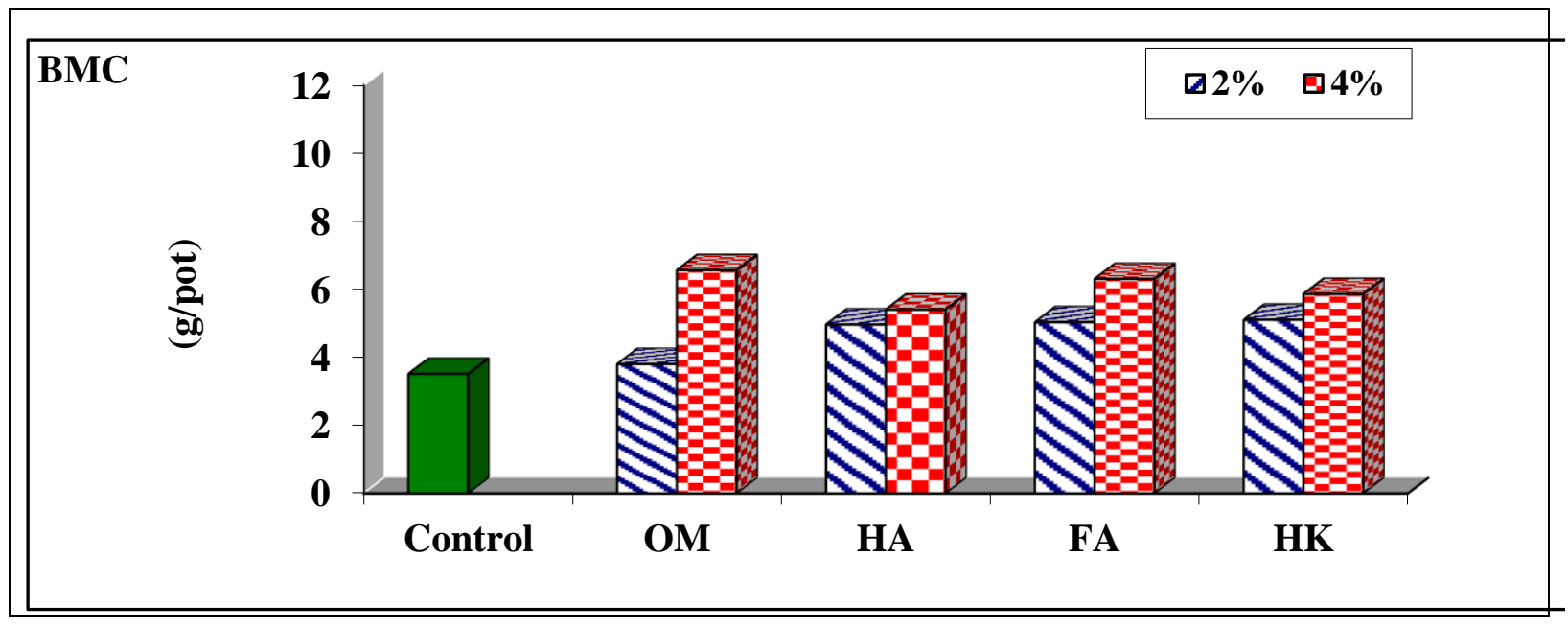




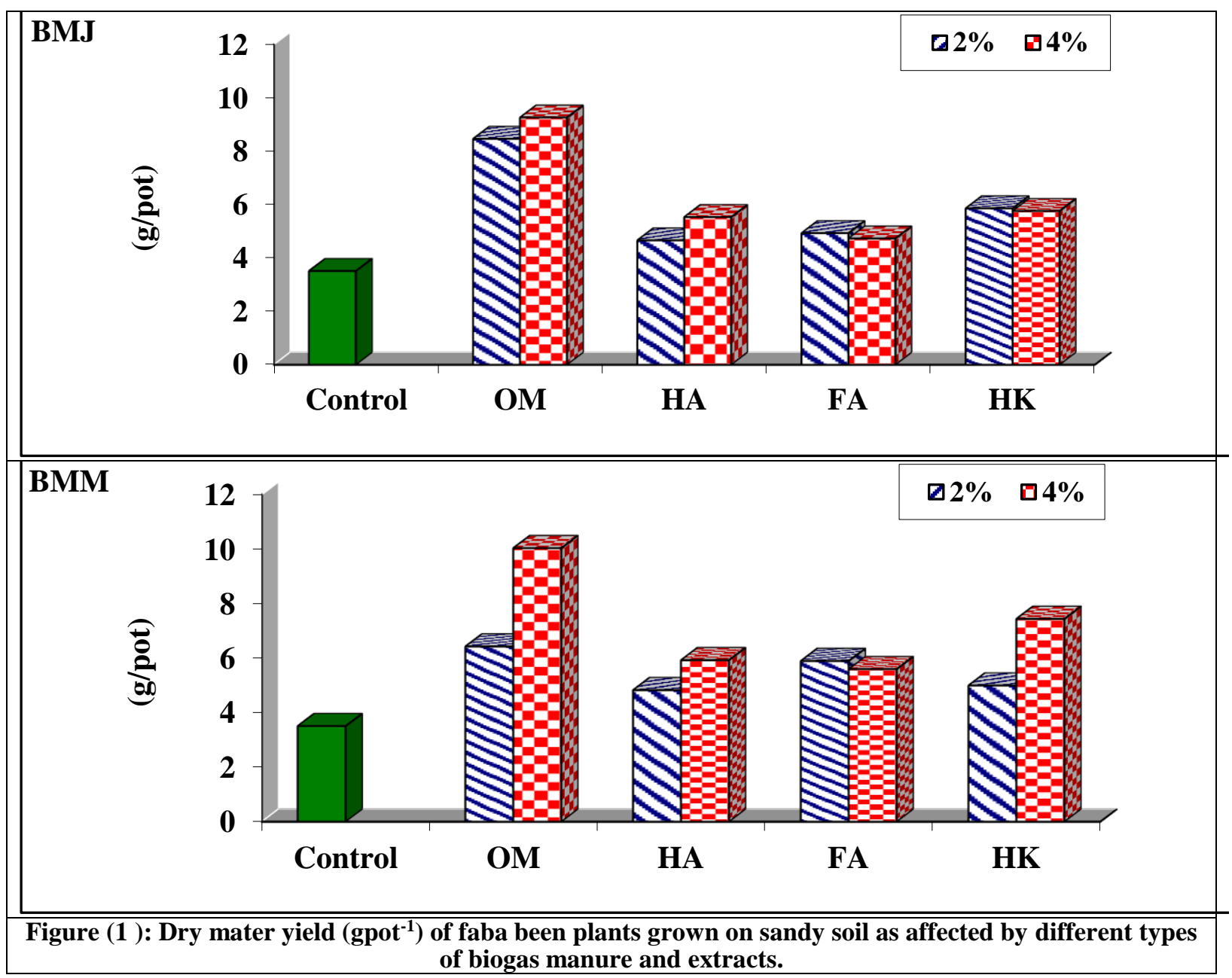

Nutrients Uptake (NPK) by faba bean plants grown on a sandy soil as affected by different biogas manures and their extracts.

Data presented in Tables 6 and illustrated in Fig 2 revealed that $\mathrm{N}$ - uptake is influenced by the fertilization treatments under study. Results indicated that the control treatment resulted in N-uptake of bean plants grown on the tested sandy soil of about 46.9 mgpot $^{-1}$. Treating this soil with, the different biogas manures significantly affected $\mathrm{N}$-uptake in the plants grown thereon. The effect seemed more obvious upon using BMC where the induced $\mathrm{N}$ uptake in the plants was about 198.6 mgpot $^{-1}$. The Nuptake in the plants treated with the BMM was the least compared with those attained due to the other biogas manures. It is about 139.3 mgpot $^{-1}$, however, this uptake exceeded that of the control treatment by about $197 \%$.

The investigated biogas manures can be arranged according to their effect on $\mathrm{N}$-uptake in the faba bean plants in the following descending order: $\mathrm{BMC}>\mathrm{BMJ}>\mathrm{BMM}$

Regarding the effect of biogas manures and their extracts on $\mathrm{N}$-uptake by faba bean plants, data in table 6 revealed that significant increases occurred due to manuring. The uptake was highest with the $\mathrm{OM}$ where it reached $171.1 \mathrm{mg}$ pot $^{-1}$. On the other hand, $\mathrm{N}$-uptake by the plants in case of HA was the lowest value giving about $94.4 \mathrm{mg} \mathrm{pot}^{-1}$, however this value is still far higher than that of the control treatment which was about $46.9 \mathrm{mg} \mathrm{pot}^{-1}$. The effect of $\mathrm{HK}$ and FA values of $\mathrm{N}$-uptake were about 100.7 and 119.1 mgpot $^{-1}$

Data also showed that as the rate of humic substances applied increased from 2 to $4 \%$, the $\mathrm{N}$ uptake also increased. Organic fertilizer plays major roles on available $\mathrm{N}$ and have greater effect on plant growth and nutrients uptake under different soil conditions (Mahmoud, 2017; Abdel-Aal, 2018; Farid et al., 2018 and Adegbite et al., 2021). According to Baris and Ali (2013), potassium humate as product of HA increases the release of primary macronutrients $\mathrm{N}, \mathrm{P}$ and $\mathrm{K}$. The liquid organic fertilizers had a promotive effect on all growth parameters including the vegetative growth, plant height, plant dry weight number, plant productivity and nutrients content $\mathrm{N}, \mathrm{P}$ and $\mathrm{K}$ in the plants (Afifi et al., 2014; Hashem, 2016 and Kumar Sootahar et al., 2019). 
Table 6. N-uptake $\left(\right.$ mgpot $\left.^{-1}\right)$ by faba bean plants grown on sandy soil as affected by different biogas manures and their extracts.

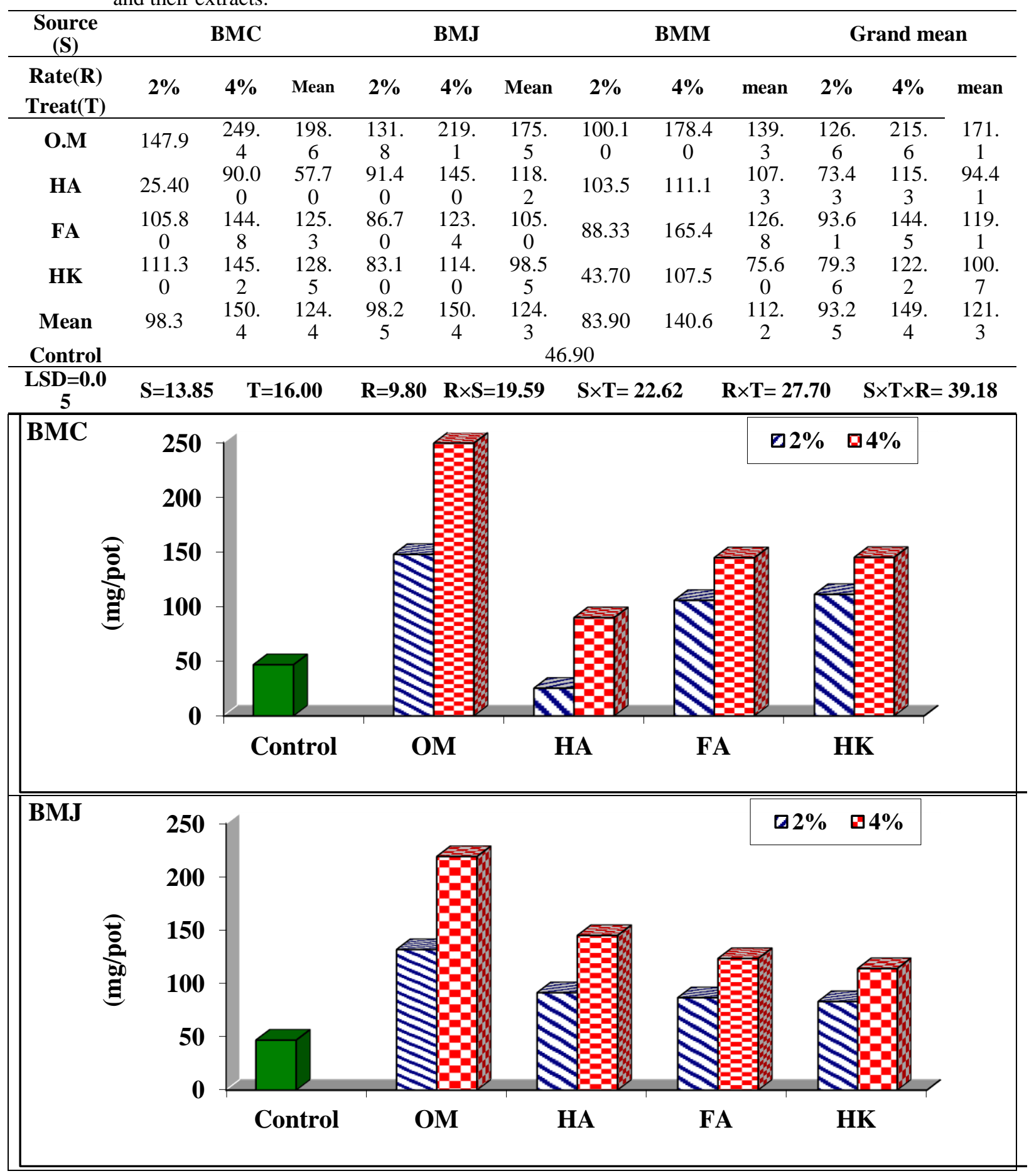




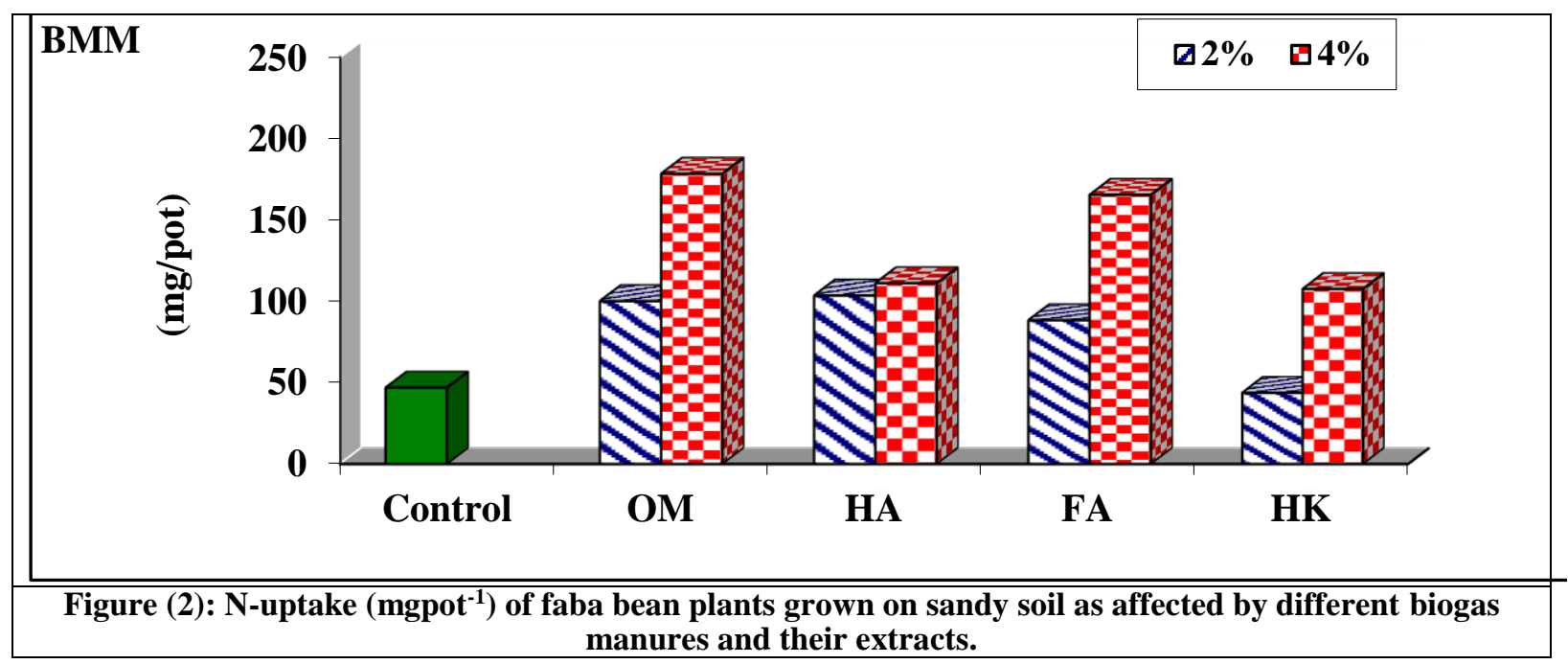

P-uptake by faba bean plants grown on a sandy soil as affected by different biogas manures and their extracts.

Data present in table 7 and illustrated in fig 3 showed that the P-uptake of faba bean plants increased by treating the tested sandy soil with the three biogas manures and their extracts as compared with the control treatment. The different biogas manures can be arranged to their effect on P-uptake in the following descending order: $\mathrm{BMC}>\mathrm{BMM}>\mathrm{MBJ}$. The corresponding values were 17.0, 9.41 and 6.26 mgpot $^{-1}$, respectively it can be deduced from the above-mentioned results that the BMC was the most efficient manure in inducing P-uptake, while BMJ was the least in the three biogas manures.

Regarding the effect of different humic substances types on P-uptake by faba bean plants, data indicated that significant increases occurred due to manuring except $\mathrm{HA}$ and $\mathrm{HK}$ with no significant variations between these two treatments. The uptake was highest with the OM where it reached $10.9 \mathrm{mg}$ pot $^{-1}$. On the other hand, P-uptake in case of HA was the lowest value giving about $6.19 \mathrm{mg} \mathrm{pot}^{-1}$.

Results revealed that $\mathrm{OM}$ was more efficient than their different extracts in increasing P-uptake by faba bean plants. Also, as the rate of biogas manures and their extracts applied increased, from 2 to $4 \%$, the P-uptake also increased. Organic manure source and compost play major roles on plant growth and sandy soil contents of available $p$ and its uptake by plants (Lee, 2016; Mahmoud, 2017 and AbdelAal, 2018). Humic acids have also demonstrated significant efficiency for increasing $\mathrm{P}$ availability (Tahir et al., 2011) and uptake by plants through minimizing $\mathrm{P}$ fixation by $\mathrm{Ca}$ in calcareous soils (Arjumend et al., 2015; Abd El-Aziz et al., 2020). This might take place via binding and electron transfer (Lee et al., 2019).

Table 7. P-uptake $\left(\right.$ mgpot $\left.^{-1}\right)$ by faba bean plants grown on sandy soil as affected by different biogas manures and their extracts.

\begin{tabular}{|c|c|c|c|c|c|c|c|c|c|c|c|c|}
\hline \multirow{2}{*}{$\begin{array}{c}\text { Source(s) } \\
\text { Rate }(\mathbf{R})\end{array}$} & \multicolumn{3}{|c|}{ BMC } & \multicolumn{3}{|c|}{ BMJ } & \multicolumn{3}{|c|}{ BMM } & \multicolumn{3}{|c|}{ Grand mean } \\
\hline & $2 \%$ & $4 \%$ & Mean & $2 \%$ & $4 \%$ & Mean & $2 \%$ & $4 \%$ & mean & $2 \%$ & $4 \%$ & mean \\
\hline \multicolumn{13}{|l|}{ Treat(T) } \\
\hline O.M & 12.8 & 21.1 & 17.0 & 3.39 & 9.13 & 6.26 & 5.90 & 12.9 & 9.41 & 7.37 & 14.38 & 10.87 \\
\hline H.A & 8.21 & 3.55 & 5.88 & 5.12 & 4.20 & 4.66 & 6.94 & 9.18 & 8.06 & 6.75 & 5.64 & 6.19 \\
\hline F.A & 10.03 & 6.16 & 8.10 & 7.88 & 8.51 & 8.20 & 5.03 & 11.30 & 8.17 & 7.64 & 8.65 & 8.14 \\
\hline H.K & 8.00 & 11.2 & 9.60 & 5.76 & 9.37 & 7.57 & 1.53 & 6.44 & 3.99 & 5.09 & 9.24 & 7.16 \\
\hline Mean & 9.77 & 10.50 & 10.13 & 5.53 & 7.80 & 6.67 & 4.85 & 9.96 & 7.40 & 6.71 & 9.47 & 8.09 \\
\hline Control & \multicolumn{12}{|c|}{2.80} \\
\hline LSD $=0.05$ & $\mathrm{~S}=1$. & & $T=1.29$ & $\mathbf{R}=$ & & $S=1.59$ & $\mathrm{~S} \times \mathbf{I}$ & $=1.83$ & $\mathbf{R} \times \mathbf{T}=$ & 24 & $\mathbf{S} \times \mathbf{T} \times \mathbf{I}$ & 3.17 \\
\hline
\end{tabular}




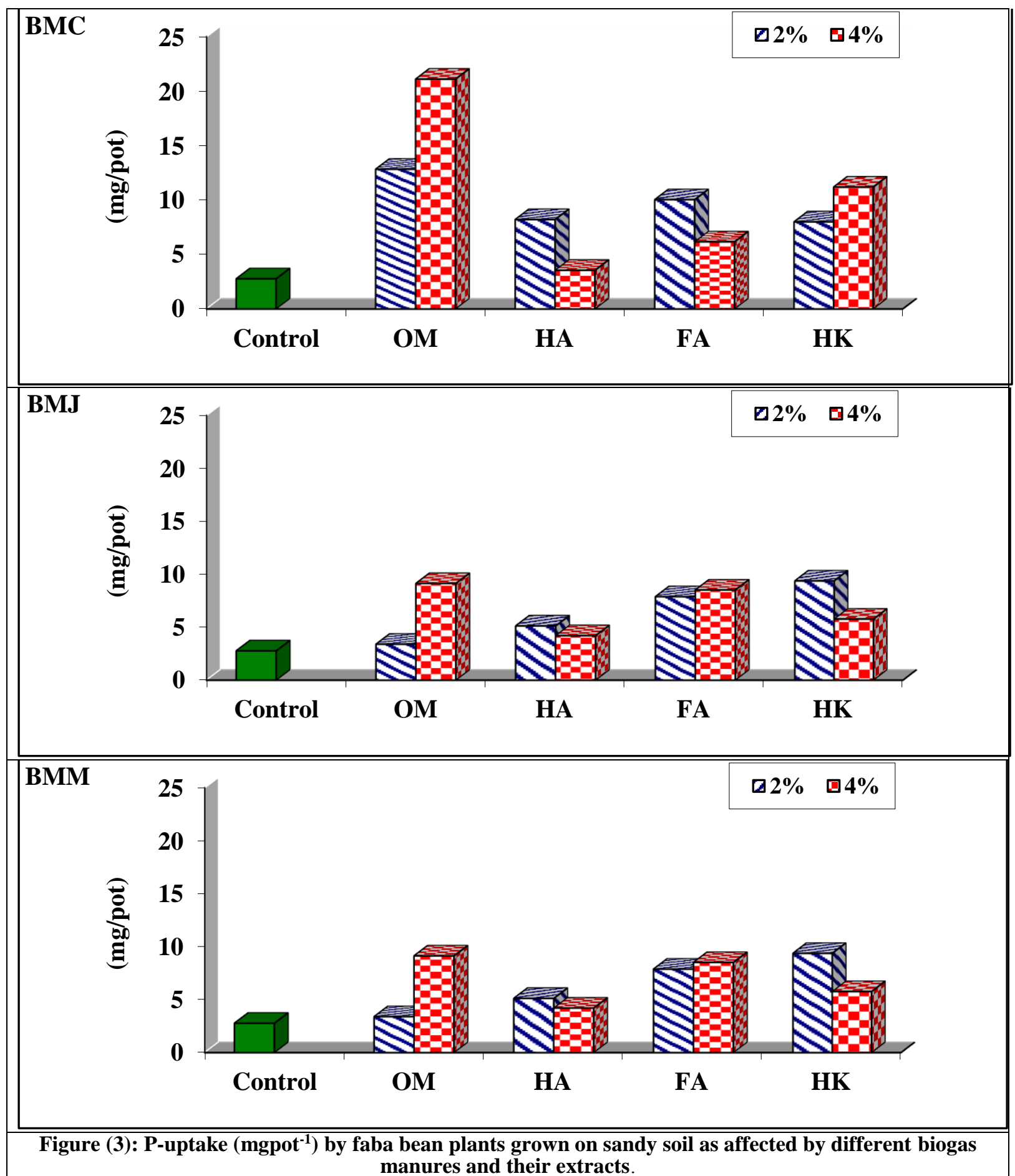

K-uptake by faba bean plants grown on a sandy soil as affected by different biogas manures and their extracts.

Data presented in Tables 8 and illustrated in Fig 4 reveal that application of the different tested organic amendments, generally resulted an increase in K-uptake by faba bean plants grown on the tested sandy soil. The effect seemed to be height upon utilization of the BMM where K-uptake was 217.7 $\mathrm{mg}$ pot $^{-1}$ on the other hand, the BMJ resulted in the lowest K-uptake in the plants grown on the sandy soil since its mean value was $112.9 \mathrm{mg}$ pot-1, however, this value is still higher than that of the control treatment which was $41.7 \mathrm{mg} \mathrm{pot}^{-1}$ only.

Concerning the effect of different treatments, data showed that significant increases occurred due to manuring. The treatments can be arranged according to their effect on K-uptake by faba bean plants in the following descending order: where the corresponding mean values were 172.3,91.7,76.8 and $55.95 \mathrm{mg} \mathrm{pot}^{-1}$, respectively.

Data also indicated that increasing rate of different biogas manures and their extracts 
application from 2 to $4 \%$ recorded significant increase in k-uptake by faba bean plants. These results agree with the findings of EL-Ghozoli (2018), Hashem (2016) Who found that increasing the rate of biogas manure and their extracts (HK, HA and FA) significantly increase K-uptake by faba bean plants grown on the sandy soil.

Table 8. K-uptake $\left(\right.$ mgpot $\left.^{-1}\right)$ by faba been plants grown on sandy soil as affected by different biogas

\begin{tabular}{|c|c|c|c|c|c|c|c|c|c|c|c|c|}
\hline \multirow{2}{*}{$\begin{array}{c}\text { Source(S } \\
\text { ) } \\
\text { Rate(R) } \\
\text { Treat(T) }\end{array}$} & \multicolumn{3}{|c|}{ BMC } & \multicolumn{3}{|c|}{ BMJ } & \multicolumn{3}{|c|}{ BMM } & \multicolumn{3}{|c|}{ Grand mean } \\
\hline & $2 \%$ & $4 \%$ & Mean & $2 \%$ & $4 \%$ & Mean & $2 \%$ & $4 \%$ & mean & $2 \%$ & $4 \%$ & mean \\
\hline O.M & 84.8 & $\begin{array}{c}287 . \\
8\end{array}$ & 186.3 & 98.9 & $\begin{array}{c}127 . \\
0\end{array}$ & $\begin{array}{c}112.9 \\
3\end{array}$ & $\begin{array}{c}116 . \\
6\end{array}$ & $\begin{array}{c}318.8 \\
0\end{array}$ & 217.7 & 100.1 & 244.52 & $\begin{array}{c}172.3 \\
1\end{array}$ \\
\hline HA & $\begin{array}{c}67.1 \\
0\end{array}$ & $\begin{array}{c}155 . \\
3\end{array}$ & $\begin{array}{c}111.2 \\
0\end{array}$ & 63.9 & $\begin{array}{c}76.3 \\
0\end{array}$ & 70.08 & 64.6 & 123.0 & 93.78 & 65.19 & 118.19 & 91.69 \\
\hline FA & $\begin{array}{c}86.1 \\
3\end{array}$ & 55.4 & 70.87 & $\begin{array}{c}57.4 \\
3\end{array}$ & 57.6 & 57.50 & 59.3 & 69.90 & 64.6 & $\begin{array}{c}50.9 \\
5\end{array}$ & 60.95 & 55.95 \\
\hline HK & $\begin{array}{c}96.5 \\
0\end{array}$ & 92.37 & 94.43 & 65.10 & 66.33 & 65.72 & 67.30 & 73.20 & 70.25 & 76.30 & 77.30 & 76.80 \\
\hline Mean & $\begin{array}{c}83.6 \\
3 \\
\end{array}$ & $\begin{array}{c}147 . \\
7 \\
\end{array}$ & $\begin{array}{c}115.6 \\
7\end{array}$ & 71.3 & 81.8 & 76.55 & 77.0 & $\begin{array}{c}146.2 \\
1 \\
\end{array}$ & $\begin{array}{c}111.5 \\
8\end{array}$ & $\begin{array}{c}73.1 \\
3 \\
\end{array}$ & $\begin{array}{c}125.2 \\
4 \\
\end{array}$ & 99.18 \\
\hline \multicolumn{2}{|c|}{ Control } & \multicolumn{11}{|c|}{41.73} \\
\hline $\mathbf{L S D}=$ & & $S=5$ & & .84 & $\mathrm{R}=3.58$ & $\mathrm{R} \times \mathrm{S}=7.1$ & & $=8.26$ & $\mathbf{R} \times \mathbf{T}=1$ & 11 & $x \mathbf{T} \times \mathbf{R}=$ & 4.30 \\
\hline
\end{tabular}

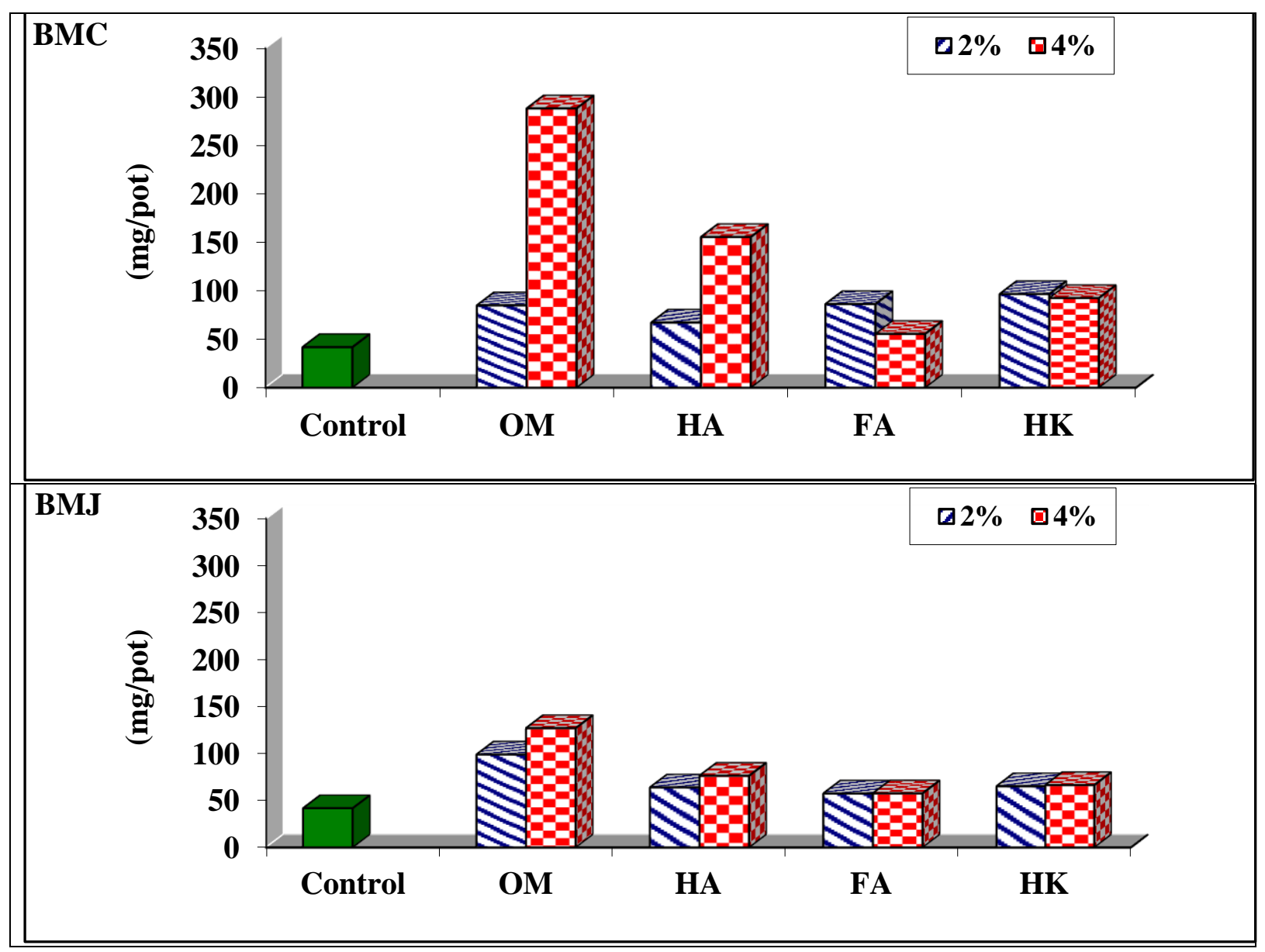




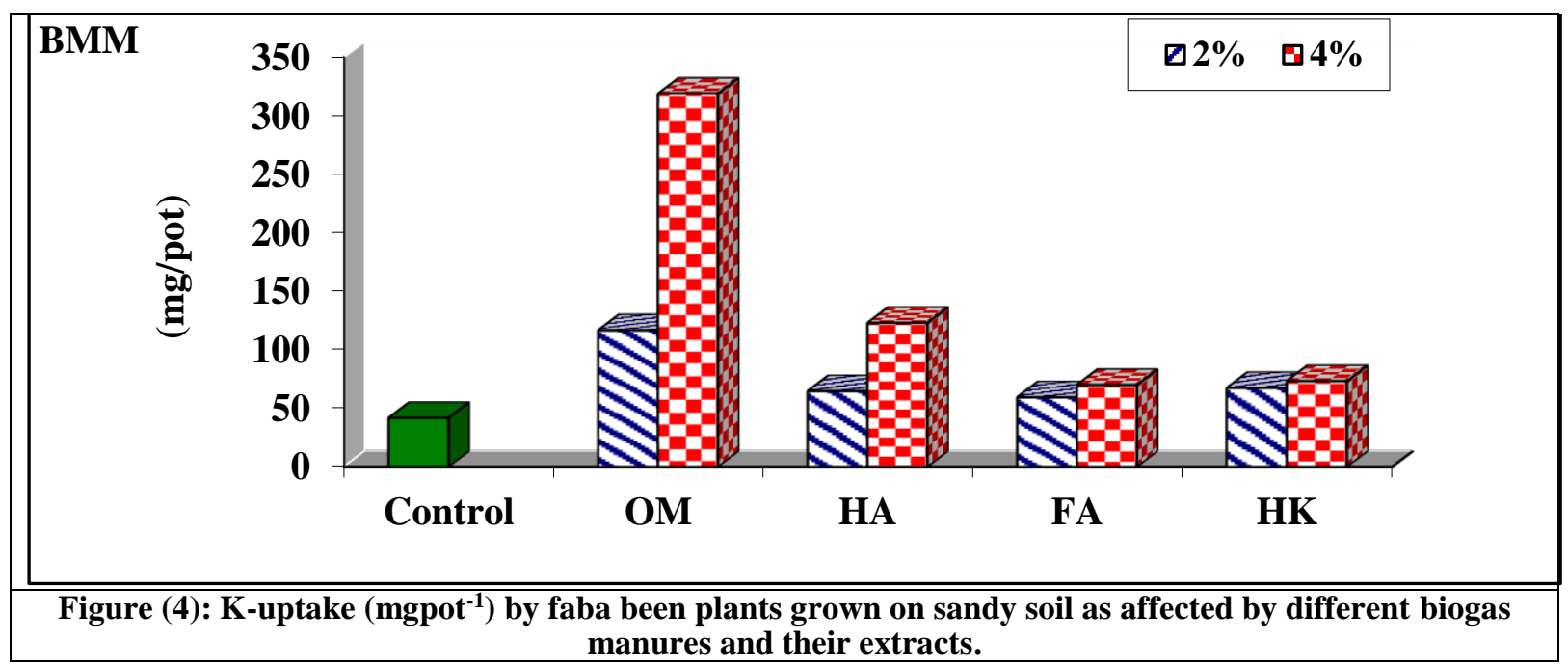

\section{Conclusion}

Application of different types of biogas manures (BMC, BMJ and BMM) and their extracts (HK, HA and FA) increased significantly NPK uptake by faba bean plants and consequently increased plant dry weights. In this concern, biogas manures were more efficient than their extracts on increasing dry matter yield and the nutrients uptake by faba bean plant. The highest increases were attained when applications of organic amendments at a rate of $4 \%$ rather than $2 \% \%$; yet the behavior of the organic amendments in soil varied considerably among the source of the organic amendment.

\section{References}

Ameri, A. and Tehranifar A. 2012. Effect of humic acid on nutrient uptake and physiological characteristic Fragaria x AnanassaVar: Camarosa. J Biol Env Sci., 6:77-79.

Abd El-Aziz, M.F., Abbas, M.H.H. and Ewis, A.M.G. 2020. Can humic acid alleviate the adverse effect of elevated phosphorus application on yield and nutritive contents of maize grown on a calcareous soil. Environment, Biodiversity and Soil Security 4, 333-343.

Abdel- Aal, M. A. M. 2018. Studies on improving of some deserted soils properties and their implication ions on plant. M. Sc. Fac. Agric., Banha Univ., Egypt.

Adegbite, E.A., Atere, C.T. and Olayinka, A. 2021. Growth, nitrogen fixation and yields of cowpea (Vigna unguiculata L. Walp) and chemical properties of an acid Alfisol in response to applications of organic amendments and inorganic N, Journal of Plant Nutrition, 44:5, 692-703.

Afifi, M. M. I. 2010. Microbiological studies during compost production from farm wastes. M. Sc. Thesis Fac. Agric., Cairo Univ., Egypt, 96 p.
Afifi, M.M.I, El- Sayed, G.A.M, Manal, A.H. E. and Massoud, O.N. 2014. Synergistic effect of biofertilizers containing $\mathrm{N}$-fixer, $\mathrm{P}$ and $\mathrm{K}$ Solubilizers and Humic Substances on Sorghum bicolor Productivity. Middle East Journal of Applied Sciences, 4 (4): 10651074.

Altuntaş, E. and Yıldız, M. 2007. Effect of moisture content on some physical and mechanical properties of faba bean (Vicia faba L.) grains, Journal of Food Engineering, 78 (1), 174-183.

Arjumend, T., Abbasi,M.K., and Rafique,E.2015. Effects of lignite-derived Humic acid on some selected soil properties, growth and nutrient uptake of wheat (Triticum Aestivum 1.) grown under greenhouse conditions. Pak. J. Bot., 47(6): 2231-2238

Baris, B. A. and Ali, V. K. 2013. Determination of effects on solid and liquid humic substances to plant growth and soil micronutrient availability. Journal of Food Agriculture \& Environment 11 (2): 1182-1186.

Boghdady, M. S., Desoky, E. M., Azoz, S. N. and Nassar, D. M. A. 2017. Effect of Selenium on Growth, Physiological Aspects and Productivity of Faba Bean (Vicia faba L.). Egypt J. Agron., 39 (1): 83- 97.

Buckman, H. O. and Brady, N. C. 1980. The nature and properties of soil, 8th ed., pp 16-137. Eurasia Publishing House (P) Ltd., New Delhi.

Cazzato, E., Tufarelli, V., Ceci, E., Stellacci, A.M. and Laudadio, V. 2012. Quality yield and nitrogen fixation of faba bean seeds as affected by sulphur fertilization. Acta Agriculturae Scandinavica Section B: Soil and Plant Science, 62: 732-738.

Chapman, H. D. and Pratt, F. P. 1961. Methods of analysis for soils, Plants and Water. Univ. California, Div. Agric., Sci. Riverside, USA.

Chen, Y., Senesl, N. and Schnitzer, M. 1978. Chemical and physical characteristics of 
humic and fulvic acids extracted from soil of the mediterranean region. Geoderma, 45: 2087.

Crepon, K., Marget, P., Peyronnet, C., Carrouée, B., Arese, P. and Duc G. 2010. Nutritional value of faba bean (Vicia faba L.) seeds for feed and food. Field Crop Res 115:329-339.

Denton, M.D., Pearce, D.J. and Peoples, M.B. 2013. Nitrogen contributions from faba bean (Vicia faba L.) reliant on soil rhizobia or inoculation. Plant Soil 365, 363-374. https://doi.org/10.1007/s11104-012-1393-2

Deublein, D. and Steinhauser, A. 2011. Biogas from Waste and Renewable Resources: An Introduction. John Wiley \& Sons.

Du Jardin, P. 2015. Plant biostimulants: definition, concept, main categories and regulation. Sci. Hortic., 196: 3-14.

El-Ghozoli,A.M. 2018. Chemical and microbiological studies on some organic fertilizers and their effects on soil. B.Sc. Agric. (Soil Sci.), Benha University

Eid, K.E., Abbas, M.H.H., Mekawi, E.M., EINagar, M.M., Abdelhafez, A.A., Amin, B.A., Mohamed, I. and Ali, M.M. 2019. Arbuscular mycorrhiza and environmentally biochemicals enhance the nutritional status of Helianthus tuberosus and induce its resistance against Sclerotium rolfsii, Ecotoxicology and Environmental Safety, 186,109783,

Elshony, M., Farid, I., Alkamar, F., Abbas, M. and Abbas, H. 2019. Ameliorating a sandy soil using biochar and compost amendments and their implications as slow-release fertilizers on plant growth. Egyptian Journal of Soil Science, 59(4), 305-322.

FAO. 2019. Food Loss and Food Waste. Food and Agriculture Organization of the United Nations (FAO). Rome, Italy.

Farid, I.M., Abbas, M.H.H., Beheiry, G.Gh.S. and Elcossy, S.A.E. 2014. Implications of organic amendments and tillage of a sandy soil on its physical properties and $\mathrm{C}$-sequestration as well as its productivity of wheat and maize grown thereon. Egypt. J. Soil Sci, 54 (2), 177194.

Farid, I.M., Abbas, M.H.H. and El-Ghozoli, A. (2018) Implications of humic, fulvic and $\mathrm{K}-$ humate extracted from each of compost and biogas manure as well as their teas on faba bean plants grown on Typic Torripsamments and emissions of soil CO2. Egypt. J. Soil Sci 58 (3), 275-298.

Franche, C., Lindström, K. and Elmerich, C. (2009) Nitrogen-fixing bacteria associated with leguminous and non-leguminous plants. Plant Soil 321, 35-59.

Gomaa, A.M. and Attia, M. 1998. The contingent interaction among specific free-living microresidents and Arbuscular Mycorrhizal Fungi under certain conditions. Third Arab Conference on Modern Biotechnology Cairo, Egypt. 14 - 17 December.

Hashem,F.A., Abd-Elrahman S. H. and Taha N. M. 2016. Soil chemical characteristics and growth of broccoli and cauliflower plants as affected by liquid organic fertilizers and irrigation water levels. 12th International conf. of Egyptian soil Sci Soc, March 7-9, Ismaeiliya, Egypt.

Jackson, M. L. 1973. Soil chemical analysis. Prentice-Hall of Englewood Cliffs, New Jersy.

Jia, Y. and. Gray, V.M (2008) Growth yield of Vicia faba L. in response to microbial symbiotic associations, S. Afric, J. Bot. 74 , $25 \mathrm{e} 32$.

Jodice, R.Luzzati,A. and Nappi,P.(1982).The influence of organic fertilizers, obtained from poplar barks on the correction of iron chlorosis of Luipinusalbusl. Plant and Soil,65:309-317

Klute, A. 1986. Physical and mineralogical methods. In part 1 . Physical and mineralogical methods, ed. 2nd Ed.ASA-SSSA-Agronomy,Madison, Wisconsin USA.

Kononova, M. M. 1966. Soil organic matter. Pergmon Press, Oxford, London, Edinburgh, New York.

Kumar Sootahar, M., Zeng, X.; Su, S., Wang, Y., Bai, L., Zhang, Y., Li, T. and Zhang, X. 2019. The Effect of Fulvic Acids Derived from Different Materials on Changing Properties of Albic Black Soil in the Northeast Plain of China.Molecules, 24, 1535. https://doi.org/10.3390/molecules24081535

Lamhy, M.A.M. 2004:Evaluation of some organic residues produced from biogas units as fertilizers and soil amendments. M.SC.Thesis,Fac.Agric.Moshtohor,Benha univ., Egypt.

Lazarovits, G. 2001. Management of soil-borne plant pathogens with organic soil amendments: a disease control strategy salvaged from the past, Canadian Journal of Plant Pathology, 23:1, 1-7.

Lee A. 2016. Nitrogen and phosphorus availability from various composted wastes for use in Irish agriculture and horticulture. $\mathrm{PhD}$ Thesis. Dublin Institute of Technology, KevinStree School of Chemical and Pharmaceutical Sciences.

Lee, S., Roh, Y. and Koh, D.-C. 2019. Oxidation and reduction of redox-sensitive elements in the presence of humic substances in subsurface environments: A review, Chemosphere, 220, 86-97.

Liu, M., Hu, F., Chen, X., Huang, Q., Jiao, J., Zhang, B. and Li, H. 2009. Organic amendments with reduced chemical fertilizer promote soil microbial development and nutrient availability in a subtropical paddy 
field: The influence of quantity, type and application time of organic amendments, Applied Soil Ecology, 42 (2), 166-175.

Macdonald, L.M., Abbott, L.K., Wong, M.T.F., Webb, M.J., Jenkins, S.N. and Farrell, M. 2018. In: CSIRO (Ed.), Biological Amendments for the Australian Grains Industry: Summary Review and Framework. CSIRO, Australia.

Mahmoud, H. A. 2017. Organic amendments and their effect on status of some nutrients in soil and plant. Ph.D. Thesis. Fac. of Agric. Menoufia Univ., Egypt.

McSorley R. 2011. Overview of organic amendments for management of plantparasitic nematodes, with case studies from Florida. Journal of nematology, 43(2), 6981.

McVicar, R., Panchuk, D., Brenzil, C., Hartley, S., Pearse, P. and Vandenberg, A. 2013. Effect of selenium on growth, physiological aspects and productivity of faba bean (Vicia faba L.) Egypt. J. Agron., 39 (1): 83-97.

Mirmohamadsadeghi, S., Karimi, K., Tabatabaei, M. and Aghbashlof, M. 2019. Biogas production from food wastes: A review on recent developments and future perspectives Bioresource Technology Reports, 7:1-10.

Mohamed, H.A. 2001. Effect of organic, mineral fertilizers and bio-stimulants on growth, yield, quality and storability of sweet potato. Ph. D. Thesis, Fac. Agric., Cairo Univ., Egypt.

Nassar, R. M.A, Shanan, N. T. and Reda, F. M. 2016. Active yeast extract counteracts the harmful effects of salinity stress on the growth of leucaena plant. Scientia Hort., 201: 61-67.

Olaetxea, M., Hita, D.D., Garcia, C.A., Fuentes, M., Baigorri, R., Mora, V., Garnica, M., Urrutia, O., Erro, J., Zamarreño, A.M., Berbara, R.L. and Garcia-Mina, J.M. 2019. Hypothetical framework integrating the main mechanisms involved in the promoting action of rhizospheric humic substances on plant root- and shoot growth. Applied Soil Ecology, 123: 521-537.

Ozmen, P. and Aslanzadeh, S. 2009. Biogas production from municipal waste mixed with different portions of orange peel. MSc. Thesis, University of Boars, School of Engineering.

Page, A.L., Miller, R.H. and Keeney, D.R. 1982. Methods of soil analysis. 2nd Edn., Amercen Society of Agronomy, Madison, WI., USA.

Pardo, T., Bernal, M.P. and Clemente, R. 2014. Efficiency of soil organic and inorganic amendments on the remediation of a contaminated mine soil: I. Effects on trace elements and nutrients solubility and leaching risk, Chemosphere, 107, 121-128.

Peixoto, M. and Pinto, H.S. 2016. Food losses and waste: reflections on the current brazilian scenario. Brazilian Journal of Food Technology, 23, e2019134.

Piper, C.S. 1950.Soil and plant Analysis.Inter. Sci. Publisher, Inc. New York, U.S.A.

Quilty, J.R. and Cattle, S.R. 2011. Use and understanding of organic amendments in Australian agriculture: a review. Soil Res., 49: $1-26$.

Rajaeifar, M.A., Ghanavati, H., Dashti, B.B., Heijungs, R., Aghbashlo, M. and Tabatabaei, M. 2017. Electricity generation and GHG emission reduction potentials through different municipal solid waste management technologies: a comparative review. Renew. Sust.Energ. Rev., 79: 414-439

Reddy, T. Y. and Reddi, G. H. S. 1992. Principal of agronomy. 1st ed., pp 190. Kalyani Publishers, Calcutta, India.

Reinhold, B., Hurek, T. and Fendrik, L. 1985. Strain specific chemotaxis of Azospirillum spp. J. Bacteriol., 162: 190 - 195.

Richards, L. A. 1954. Diagnosis and improvement of saline and alkali soil. Agricultural Handbook no. 60 U.S.Dept. Agric.

Rizk, F.A. and Shafeek, M.R. 2000. Response of growth and yield of Vicia faba plants to foliar and bio-fertilizers. Egypt. J. Appl. Sci., 15 (12): $652-670$.

Ryan, B. F. and Joiner, B.L. 1994. Mintab Handbook. Third Edition, An Imprint of Wadsworth Publishing company Belmont, California.

Sanchez- Monedero, M. A., Roid, A., Cegarra, J., Bernal, M. P. and Paredes, C. 2002. Effects of HCL-HF purification treatment on chemical composition and structure of humic acids. European Journal Soil Sci., 53: 375 - 381.

Sani, B. 2014. Foliar application of humic acid on plant height in Canola. APCBEE Procedia, 8: 82- 86.

Sharaan, A.N., Ekram, A., Megawer, H.A.S. and Hemida, Z.A. 2004. Seed yield, yield components and quality character as affected bycultivars, sowing dates and planting distances in faba bean. Bull. Agric. Econ. Min. Agric. Egypt

Susilawati,K., Ahmed,o.H., Muhamad, A.B.N. and Khanif, M.Y. 2007. Effects of extraction and fractionation period on the yield of a tropical peat soil (Hemists) humic acids.AM.J.Agric. Biol.Sci., 2 (3):202-205

Tahir, M.M., Khurshid,M. Khan, M.Z. Abbasi, M.K. and Kazmi, M.H. 2011. Lignite-derived humic acid effect on growth of wheat plants in different soils. Pedosphere, 21:124-131.

Turan, M. A., Baris, B. A., Katkat, A. V., and Celik, H. 2011. The effects of soil applied humic substances to the dry weight and mineral nutrient uptake of maize plants under soil-salinity 
conditions. Notulae Botanicae Horti Agrobotanici Cluj-Napoca, 39 (1): 171-177.

Xu, F., Li, Y., Ge, X., Yang, L. and Li, Y. 2018.

Anaerobic digestion of food waste - challenges and opportunities. Bioresour. Technol., 247: $1047-1058$

تأثير اسمده البيو جاز المختلفة ومستخلصاتها على محصول المادة الجافه والعناصر الغذائية الممتصة بواسطة الفول

$$
\text { البلاي المزروع في ظروف تريه رملية. }
$$

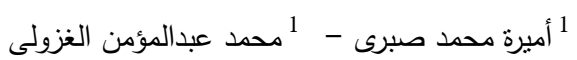

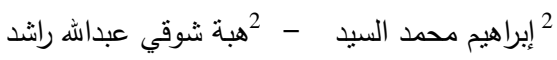

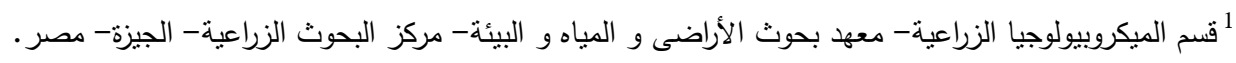

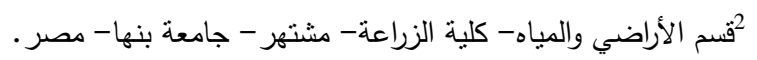

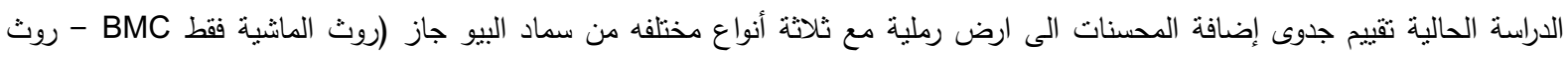

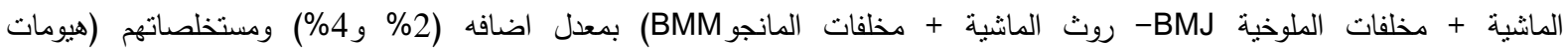

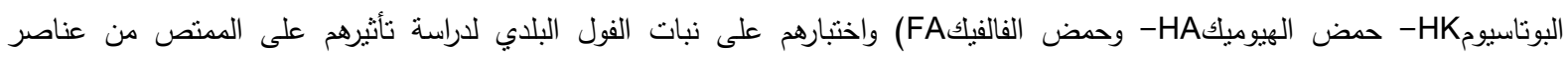

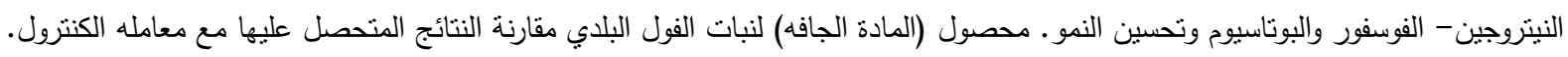

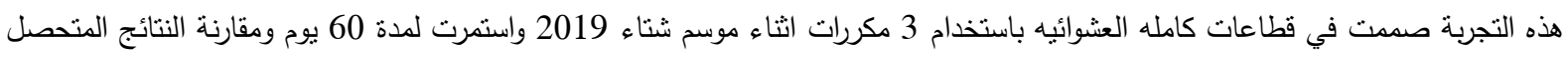

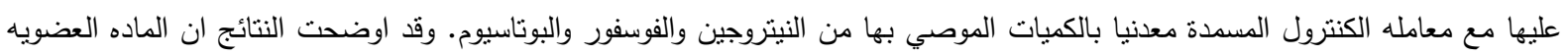

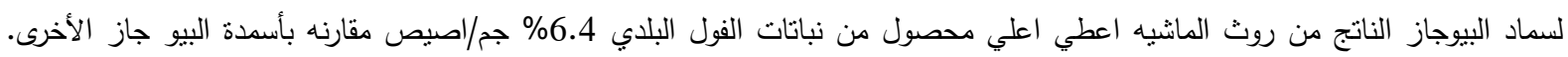

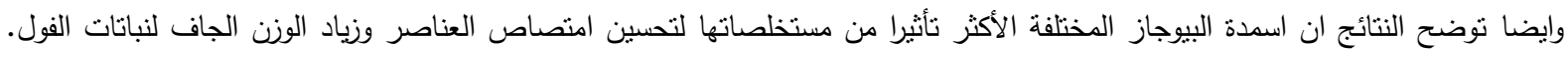

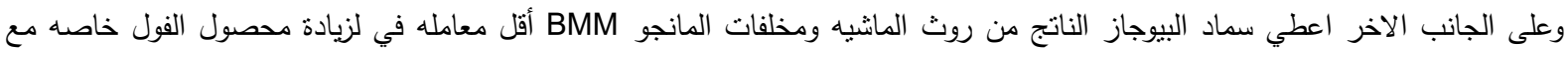

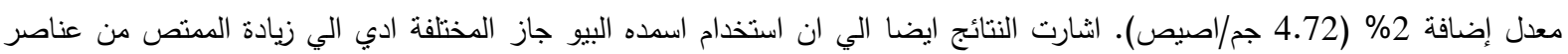
النيتروجين والفوسفور والبوتاسيوم وبخاصة عند معدل إضافة 4\%، حيث ان سلوك المحسنات العضوية في التربة يتغير بتغير مصدرها. 